\title{
POTENSI ANTIBAKTERI BINTANG LAUT DARI PERAIRAN PANTAI KELURAHAN TONGKAINA MANADO
}

\author{
(The Antibacterial Potential of Starfish from the Coastal waters of the Kelurahan Tongkaina)
}

\author{
Delpris Piter ${ }^{1^{\star}}$, Esther D. Angkouw ${ }^{1}$, Fitje Losung ${ }^{1}$
}

1. Program Studi IImu Kelautan, Fakultas Perikanan dan Ilmu Kelautan, Universitas Sam Ratulangi, Manado

*e-mail: delpristilly@gmail.com

Abstract

\begin{abstract}
Starfish is one of the species of the asteroidean class, and is grouped into phylum echinoderms. Echinoderms consist of approximately 6000 species and all live in sea water. Starfish is one source bioactive compounds. Active compounds from starfish have been known to have activities antioxidant, antibacterial, antiinflammatory, antifungal and immunostimulatory, there are also blue starfish that are potential as antitumor and antibacterial agents. This study aims to obtain crude extracts from several types of starfish, and testing the antibacterial activity of crude starfish extracts against bacteria Streptococcus agalactiae, Escherichia coli and Staphylococcus aureus. Test the antibacterial activity of crude starfish extracs Protoreaster nodosus, Achaster tipycus, dan Linckia laevigata against bacteria E. coli, S. aureus, dan S. agalactiae use the agar diffusion method by means of a well. L. I extract can inhibit bacteria e. coli at an extract concentration of $1000 \mathrm{mg} / \mathrm{ml}$ with a diameter of inhibitory zone $11.0 \mathrm{~mm}$, whereas at a concentration of $750 \mathrm{mg} / \mathrm{ml}$ the test bacteria can still grow on the bacteria $S$. agalactiae and $S$. aureus can still grow even though the extract has be given $L$. I
\end{abstract}

Keywords: Potential Starfish, Antibacterial Activity, Staphylococcus aureus, Escherichia coli, and Streptococcus agalactiae

Abstrak

Bintang laut merupakan salah satu spesies dari kelas Asteroidea, dan dikelompokkan kedalam filum Echinodermata. Filum Echinodermata terdiri atas kurang lebih 6000 spesies dan semuanya hidup di air laut. Bintang laut merupakan salah satu sumber penghasil senyawa bioaktif. Senyawa aktif dari bintang laut telah diketahui memiliki aktivitas antioksidan, antibakteri, antiinflamasi, antifungi dan imunostimulator, ada juga bintang laut biru yang potensial sebagai antitumor dan agen antibakteri. Penelitian ini bertujuan untuk mendapatkan ekstrak kasar dari beberapa jenis bintang laut, dan menguji aktivitas antibakteri ekstrak kasar bintang laut terhadap bakteri Streptococcus agalactiae, Escherichia coli dan Staphylococcus aureus. Uji aktivitas antibakteri dari ekstrak kasar bintang laut Protoreaster nodosus, Achaster tipycus, dan Linckia laevigata terhadap bakteri E. coli, S. aureus, dan S. agalactiae mengggunakan metode difusi agar dengan cara sumur. Ekstrak L. I mampu menghambat bakteri E.coli pada konsentrasi ekstrak $1.000 \mathrm{mg} / \mathrm{ml}$ dengan diameter zona hambat $11.0 \mathrm{~mm}$, sedangkan pada konsentrasi $750 \mathrm{mg} / \mathrm{ml}$ bakteri uji masih bisa bertumbuh pada bakteri $S$. agalactiae dan $S$. aureus masih dapat bertumbuh walaupun telah diberikan ekstrak $L$. I.

Kata Kunci : Potensi Bintang Laut, Aktivitas Antibakteri, Streptococcus agalactiae, Escherichia coli and Staphylococcus aureus

\section{PENDAHULUAN}

Salah satu hasil perairan yang merupakan kekayaan alam laut Indonesia ialah bintang laut. Bintang laut merupakan salah satu spesies dari kelas Asteroidea, dan dikelompokkan ke dalam filum Echinodermata. Filum Echinodermata terdiri atas kurang lebih 6000 spesies dan semuanya hidup di air laut. Secara umum Echinodermata berarti hewan yang berkulit duri. Hewan ini memiliki kemampuan autotomi serta regenerasi bagian tubuh yang hilang, putus atau rusak. Semua hewan yang termasuk dalam kelas ini bentuk tubuhnya simetri radial dan kebanyakan mempunyai endoskeleton dari zat kapur dengan memiliki tonjolan berupa duri (Lariman, 2011).

Pemanfaatan sumber biota laut selain sebagai sumber pangan, juga berpotensi 
sebagai sumber senyawa bioaktif yang lebih bernilai ekonomis (Hafiluddin, 2011). Bintang laut merupakan salah satu sumber penghasil senyawa bioaktif. Bintang laut memiliki komponen bioaktif yang terdiri dari alkaloid, steroid, flavonoid, saponin, ninhidrin. (Ivanchina et al., 2011; Tarman, et al., 2012). Senyawa aktif dari bintang laut telah diketahui memiliki aktivitas antioksidan (Agustina, 2012), antibakteri (Juariah et al., 2014), antiinflamasi, antifungi dan imunostimulator (Achmad et al., 2014). Ada juga bintang laut biru yang potensial sebagai antitumor dan agen antibakteri (Mojica, at al., 2003).

Permasalahan saat ini ialah resistensi bakteri terhadap beberapa jenis antibiotik yang sudah lama digunakan. Hal ini mendorong perlunya kajian senyawa antibakteri dari bintang laut. Antibakteri merupakan zat yang dapat menghambat pertumbuhan atau bahkan dapat mematikan bakteri dengan cara merusak metabolismenya (Madigan et al., 2012). Berdasarkan uraian diatas maka peneliti merasa perlu untuk melakukan penelitian tentang aktivitas antibakteri dari beberapa ekstrak kasar bintang laut dalam upaya penemuan senyawa bioaktif antibakteri bakteri baru dari bahan alam laut.

Penelitian ini bertujuan untuk mendapatkan ekstrak kasar dari beberapa jenis bintang laut, dan Menguji aktivitas antibakteri dari beberapa ekstrak kasar bintang laut terhadap bakteri Streptococcus agalactiae, Escherichia coli dan Staphylococcus aureus.

\section{METODE PENELITIAN \\ Lokasi Pengambilan Sampel}

Organisme bintang laut jenis

L.laevigata, A. typicus, $P$. nodosus diambil dari perairan laut Tongkaina Manado.

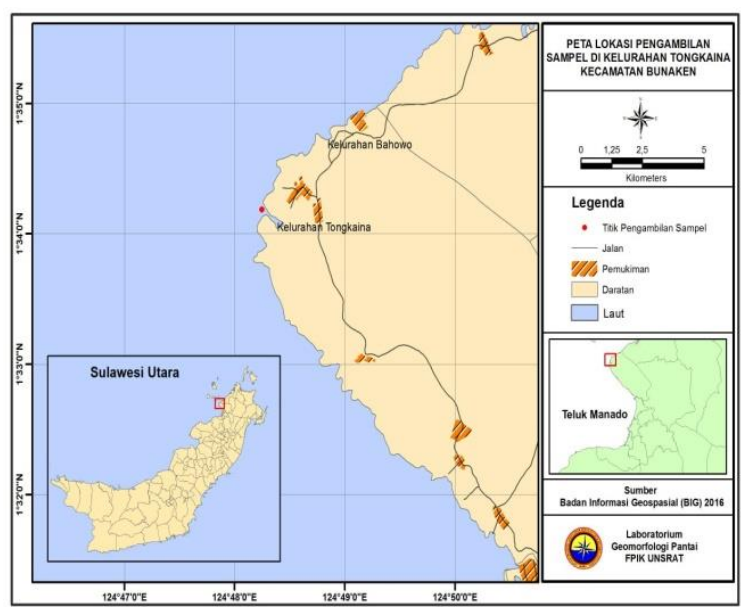

Gambar 1. Peta Lokasi Pengambilan Sampel Bintang Laut di Perairan Pantai Tongkaina Manado.

Sampel bintang laut $L$. laevigata, $A$. typicus, $P$. nodosus yang diproleh dibawa ke Laboratorium Biologi Molekuler dan Farmasitika Laut, Fakultas Perikanan dan IImu Kelautan Universitas Sam Ratulangi Manado untuk diekstraksi, evaporasi dan uji aktivitas antibakteri.

\section{Ekstraksi Bintang Laut}

Sampel L. laevigata, $A$. typicus, $P$. nodosus dimasukan kedalam botol yang sudah diberikan etanol 96\% sebanyak $750 \mathrm{ml}$ diberikan label. Sampel di saring sehingga diperoleh filtrate. Filtrat yang diperoleh, dievaporasi menggunakan "Rotary Vaccum Evaporator" pada suhu $40^{\circ} \mathrm{C}$.

\section{Sterilisasi Alat dan Media}

Alat-alat yang digunakan disterilkan dalam oven pada suhu $160^{\circ} \mathrm{C}$ selama \pm 2 jam (sterilisasi kering). Sedangkan media yang digunakan, disterilisasi dalam autoklaf pada suhu $121^{\circ} \mathrm{C}$ selama 15 menit (sterilisasi basah).

\section{Pembuatan Media}

Prosedur kerja pembuatan_media Nutrient Agar (NA) sebagai berikut : $1 \mathrm{~g}$ Nutrient Broth (NB), 1,5 g Agar dan $100 \mathrm{ml}$ aquades dimasukkan ke dalam erlenmeyer dan diaduk. erlenmeyer yang berisikan media ditutup dengan aluminium foil kemudian disterilisasi dengan menggunakan autoklaf selama \pm 15 menit dengan suhu $121^{\circ} \mathrm{C}$. media 
NA yang steril dituang secara aseptik ke dalam cawan petri steril secara merata. Setelah itu media didiamkan hingga mengeras dan sisi cawan petri dibungkus untuk menghindari kontaminasi.

\section{Kultur Bakteri Uji}

Bakteri uji yang dipakai ialah: $S$. agalactiae, E. coli dan bakteri $S$. aureus yang tersedia di laboratorium. Masing-masing bakteri diambil menggunakan jarum ose lalu dimasukan kedalam erlemeyer yang sudah berisikan Nutrient Broth (NB), kemudian tutup dengan alumunium foil dan diinkubasi pada suhu ruangan selama 24 jam.

\section{Pengenceran Sampel Bintang Laut}

Pengenceran dilakukan untuk mendapatkan hasil dari beberapa konsentrasi yang dipakai yaitu: kosentrasi $500 \mathrm{mg} / \mathrm{ml}$, konsentrasi $750 \mathrm{mg} / \mathrm{ml}, 1000 \mathrm{mg} / \mathrm{ml}$ untuk dilakukkan pengujian aktivitas antibakteri.

Rumus pengenceran: (M1.V1 = M2.V2)

\section{Pengujian Aktivitas Antibakteri}

Metode yang digunakan pada pengujian aktivitas antimikroba adalah metode difusi agar (disc diffusion, Kirby dan Bauer) dengan cara sumur. . Media agar (NA) $200 \mathrm{ml}$ yang sudah steril dituangkan pada cawan petri yang steril sebagai lapisan bawah. Setelah lapisan bawah mengeras di atasnya dituangkan media agar cair yang mengandung bakteri uji sebagai lapisan pembenihan. Setelah lapisan pembenihan mengeras, dibuat lubang/sumur menggunakan pipet sebagai alat untuk pembuatan lubang/sumur, kemudian pada lubang/sumur di dalamnya dimasukan ekstrak kasar dari bintang laut sebanyak $50 \mu \mathrm{l}$. Selanjutnya diinkubasi pada suhu ruangan selama 24 jam. Setelah itu diamati dan di ukur diameter zona hambat yang terbentuk, berupa daerah bening di sekeliling lubang

\section{HASIL DAN PEMBAHASAN}

\section{Hasil Sampling dan Identifikasi}

Sampel bintang laut yang diambil dari pantai Tongkaina Manado sebanyak 3 jenis telah diidentifikasi berdasarkan WoRMS taxon details (2018), Linckia laevigata, Archaster typicus, dan Protoreaster nodosus. Ciri bintang launt ini pada saat didapati dilapngan :

\section{A. Linckia laevigata yaitu :}

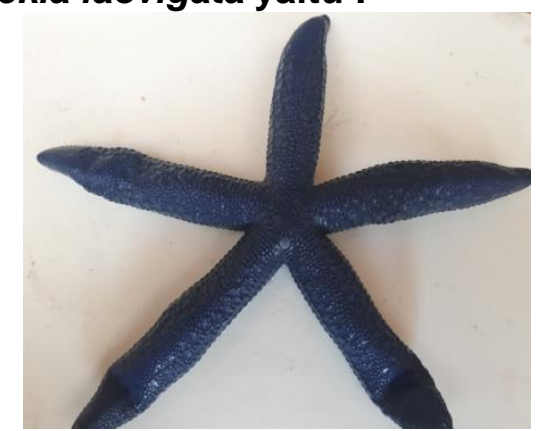

Gambar 2: Linckia laevigata (Dokumentasi Pribadi, 2019)

1. Memiliki 5 buah lengan.

2. Warna biru terang pada bagian dorsal dan kuning pada bagian oral,

3. Mulut terdapat di bawah yaitu di bagian oral, sedangkan anus di bagian aboral

4. Dorsal dan aboral terdapat duri-duri kecil.

5. Hidup pada wilayah yang multilevel dangkal di cela-cela terumbu karang dengan suhu air berkisar dari $22^{\circ} \mathrm{C}$ sampai $26^{\circ} \mathrm{C}$.

\section{B. Archaster typicus :}

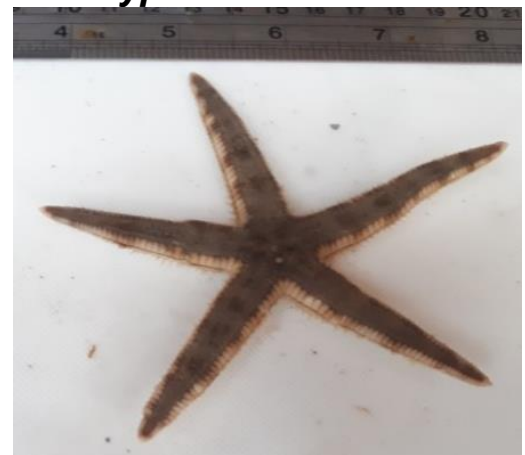

Gambar 3: Archaster typicus (Dokumentasi Pribadi, 2019)

1. Memiliki lima buah lengan atau kelipatan lima

2. Mulut terdapat dibagian bawah (oral), sedangkan anus di bagian obral,

3. Warna pada bagian coklat muda pada bagian dorsal, dan warna pada kuning pada bagian oral.

4. Terdapat ambulakral groove di antara barisan kaki tabung

5. Terdapat duri-duri yang terbentuk catut yang disebut pedicellaria

6. Bagian tubuhnya di sebelah aboral terdapat duri-duri yang tumpul. 
7. Pergerakan dilakukan oleh kaki tabung yang terdapat berderet disepanjang lengan.

8, Hidup di wilayah multilevel pada tumpukan pasir.

\section{Protoreaster nodosus :}

\section{Gambar 4:Protoreaster nodosus}

(Dokumentasi Pribadi, 2019).

1.Mempunyai lengan sebanyak 5 buah atau kelipatan dari lima

2. Mulut terdapat di bawah yaitu di bagian oral, sedangkan anus di bagian aboral

3. Pergerakan dilakukan oleh kaki tabung yang terdapat berderet sepanjang lengannya

4. Terdapat ambulakral groove di antara barisan kaki tabung,

5. Mempunyai beberapa amacam warna: kuning, orange, dan coklat keabu-abuan.

6. Bagian tubuhnya di sebelah aboral terdapat duri-duri yang tumpul berwarna hitam.

7. Hidup pada wilayah yang multilevel dangkal di cela-cela terumbu karang dengan suhu air berkisar dari $22^{\circ} \mathrm{C}$ sampai $26^{\circ} \mathrm{C}$.

\section{Ekstrak Bintang Laut}

Ekstraksi sampel ini menggunakan pelarut etanol $96 \%$ karena pelarut etanol menyari hampir keseluruhan kandungan simplisia baik non polar, semi polar maupun polar (Iswanti, 2009).
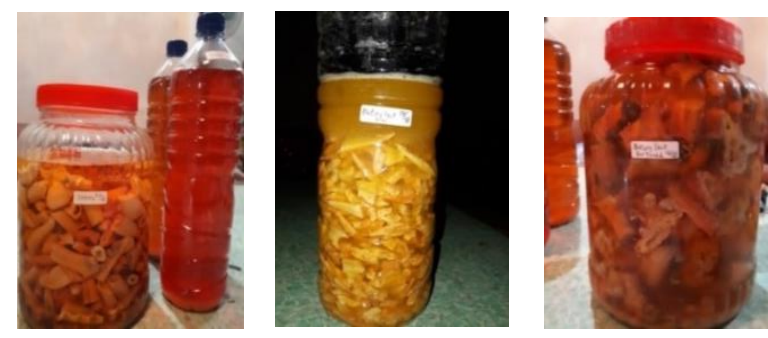

Gambar 5. Maserasi Sampel Bintang Laut

(Dokumentasi pribadi, 2019).

Filtrat yang diperoleh dari hasil maserasi (perendaman) mempunyai warna yang berbeda Linckia laevigata $(L$. I ) berwarna merah, Archaster typicus $(A$. $t)$ berwarna kuning dan Protoreaster nodosus $(P . \quad n)$ berwarna merah. . Evaporasi dilakukan untuk memperoleh ekstrak kasar bintang laut. Ekstrak kasar bintang laut yang diperoleh berupa: cairan dan ada yang kental dipindahkan ke dalam botol kosong seperti pada gambar 3. Berat ekstrak kasar masingmasing sampel bintang laut terdapat pada Tabel 2.

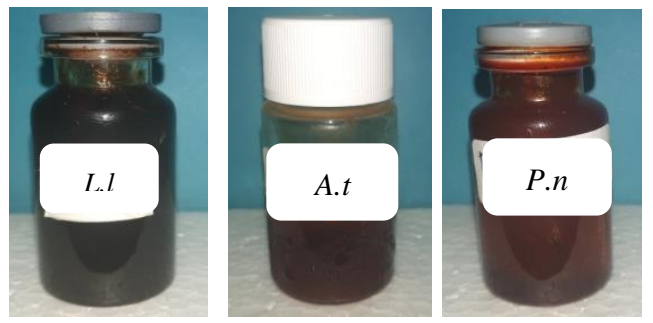

Gambar 6 . Ekstrak Kasar Bintang Laut, Keterangan : (L. I) Linckia laevigata, (A.t) Archaster tipycus, (P.n) Protoreaster nodosus, (Dokumentasi pribadi, 2019)

Tabel 1. Berat Ekstrak Kasar Bintang Laut

\begin{tabular}{lllll}
\hline No & $\begin{array}{l}\text { Kode } \\
\text { sampel }\end{array}$ & $\begin{array}{l}\text { Berat } \\
\text { Sampel } \\
\text { basah } \\
\text { (g) }\end{array}$ & $\begin{array}{l}\text { Berat } \\
\text { ekstrak } \\
(\mathbf{g})\end{array}$ & $\begin{array}{l}\text { Presentasi } \\
\text { berat } \\
\text { ekstrak } \\
(\%)\end{array}$ \\
\hline 1. & L. I & 2000 & 25.3 & $1.3 \%$ \\
\hline 2. & A. $t$ & 1000 & 14,9 & $0.7 \%$ \\
\hline 3. & P. $n$ & 2000 & 32.3 & $1.6 \%$ \\
\hline
\end{tabular}

berat ekstrak dari pelarut etanol yang terbesar ditunjukan oleh $P$. nodosus dan presentasi ekstrak kasar $1.6 \%$ diikuti oleh dua jenis bintang laut lainnya yaitu L. lavigata $1.3 \%$ dan $A$. typicus $0.7 \%$. Ekstrak kasar bintang 
laut $L$. laevigata berwarna merah-kehitaman, $A$. tipycus berwarna merah-darah, dan $P$. nodosus merah-tua.

\section{Aktivitas Antibakteri Bintang Laut}

Uji aktivitas antibakteri dari beberapa ekstrak kasar bintang laut terhadap bakteri $E$. coli, S. aureus, dan $S$. agalactiae mengggunakan metode difusi agar dengan cara sumur Metode difusi menjadi metode yang dipilih dalam uji aktivitas karena memiliki kelebihan yaitu prosedurnya yang sederhana (mudah dan praktis) untuk dilakukan dan merupakan metode serbaguna bagi semua bakteri patogen yang tumbuh cepat dan sering digunakan dalam uji kepekaan antibiotik dalam program pengendalian mutu (Mapila, 2012).

Bakteri uji yang digunakan adalah $S$. aureus, $S$, agalactiae dan E. coli dimana $S$. aureus, $S$, agalactiae mewakili bakteri gram positif dan E. coli untuk mewakili bakteri gram negatif. Penggunaan bakteri ini bertujuan untuk mengetahui bahwa apakah ekstrak kasar dari bintang laut memiliki aktivitas antibakteri serta mengetahui spektrum aktivitas antibakteri dari beberapa ektsrak bintang laut,

Dari penelitian ini ekstrak kasar $L$. laevigata menunjukkan adanya zona hambat pada pertumbuhan bakteri uji E. coli seperti terlihat pada Gambar 16 dan Tabel 3.
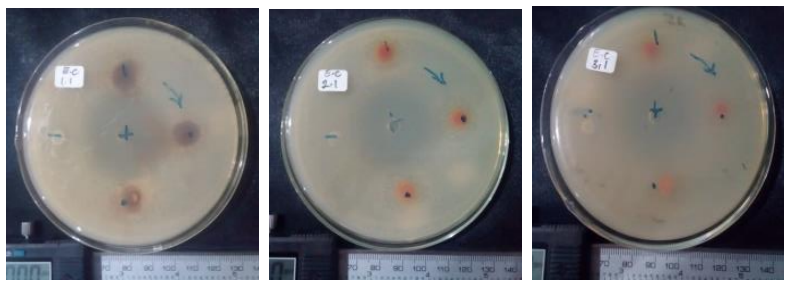

Gambar 7 : Aktivitas Antibakteri Ekstrak Bintang Laut terhadap Bakteri E.Coli. (Dokumentasi pribadi, 2019).

Keterangan: (E.c 1) : Ekstrak kasar L. laevigata pada media bakteri. (E.c 2) : Ekstrak kasar $P$. nodosus pada media bakteri. (E.c 3) : Ekstrak kasar A. typicuc pada media bakteri, + (Kontrol positif) dan - (Kontrol negatif).
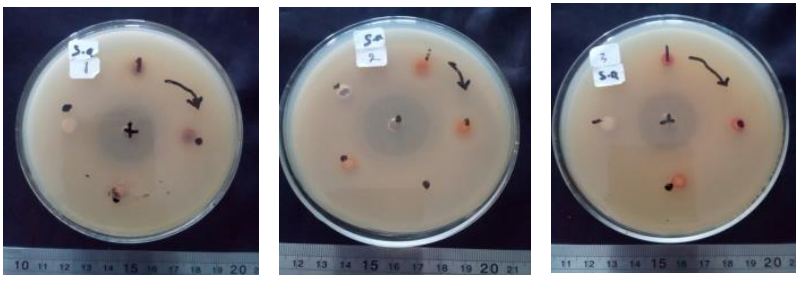

Gambar 8 : Pengujian Aktivitas Antibakteri dari Ekstrak terhadap bakteri S.aureus, (Dokumentasi pribadi, 2019).

Keterangan : (S.a 1) : Ekstrak kasar L. laevigata pada media bakteri (S.a 2) : Ekstrak kasar $P$. nodosus pada media bakteri. (S.a 3) : Ekstrak kasar A. typicuc pada media bakteri. + (Kontrol positif) - (Kontrol negatif)
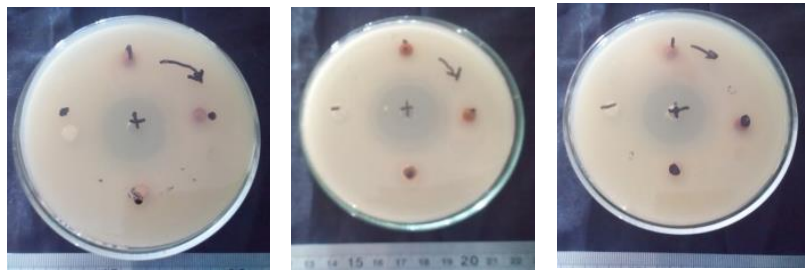

Gambar 9. Pengujian Aktivitas Antibakteri dari Ekstrak terhadap bakteri $S$. agalactiae, (Dokumentasi pribadi, 2019).

Keterangan : (S.g 1) : Ekstrak kasar L. laevigata pada media bakteri (S.g 2) : Ekstrak kasaras $P$. nodosus pada media bakteri. (S.g 3) : Ekstrak kasar $A$. typicus pada media bakteri. + (Kontrol positif) - (Kontrol negatif)

Tabel 2. Diameter Zona Hambat dari Bakteri E. coli

\begin{tabular}{|c|c|c|c|c|}
\hline \multirow[t]{2}{*}{$\begin{array}{l}\text { Kode } \\
\text { Sampel }\end{array}$} & \multicolumn{4}{|c|}{$\begin{array}{c}\text { Ulangan } \\
\text { Ekstrak } 1000 \mathrm{mg} / \mathrm{ml}\end{array}$} \\
\hline & 1 & 2 & 3 & Rerata \\
\hline L. I & $\begin{array}{c}11.74 \\
\mathrm{~mm}\end{array}$ & $\begin{array}{l}9.18 \\
\mathrm{~mm}\end{array}$ & $\begin{array}{c}11.69 \\
\mathrm{~mm}\end{array}$ & $\begin{array}{l}10.0 \\
\mathrm{~mm}\end{array}$ \\
\hline A. $t$ & 0 & 0 & 0 & 0 \\
\hline P. $n$ & 0 & 0 & 0 & 0 \\
\hline+ & $\begin{array}{l}21 \\
\mathrm{~mm}\end{array}$ & $\begin{array}{c}25 \\
\mathrm{~mm}\end{array}$ & $\begin{array}{c}23 \\
\mathrm{~mm}\end{array}$ & $23 \mathrm{~mm}$ \\
\hline- & 0 & 0 & 0 & 0 \\
\hline $\begin{array}{l}\text { Kode } \\
\text { Sampel }\end{array}$ & \multicolumn{4}{|c|}{$\begin{array}{c}\text { Ulangan } \\
\text { Ekstrak } 750 \mathrm{mg} / \mathrm{ml}\end{array}$} \\
\hline
\end{tabular}




\begin{tabular}{|c|c|c|c|c|}
\hline & $\mathbf{1}$ & $\mathbf{2}$ & $\mathbf{3}$ & Rerata \\
\hline L. I & 0 & 0 & 0 & 0 \\
\hline $\boldsymbol{A} . \boldsymbol{t}$ & 0 & 0 & 0 & 0 \\
\hline $\boldsymbol{P .} \boldsymbol{n}$ & 0 & 0 & 0 & 0 \\
\hline $\boldsymbol{+}$ & 20 & 21 & 23 & $21.3 \mathrm{~mm}$ \\
& $\mathrm{~mm}$ & $\mathrm{~mm}$ & $\mathrm{~mm}$ & \\
\hline- & 0 & 0 & 0 & 0 \\
\hline
\end{tabular}

Data yang ditampilkan pada Tabel 3, menunjukkan bahwa ekstrak L. I mampu menghambat bakteri E.coli. pada konsentrasi ekstrak $1.000 \mathrm{mg} / \mathrm{ml}$ dengan diameter zona hambat $11.0 \mathrm{~mm}$. Sedangkan pada konsentrasi $750 \mathrm{mg} / \mathrm{ml}$ bakteri uji masih bisa bertumbuh. Pada pengujian ini juga didapatkan hasil bahwa ekstrak L.I mampu menghambat pertumbuhan bakteri $E$. coli sedangkan pada bakteri $S$. agalactiae dan $S$. aureus masih dapat bertumbuh walaupun telah diberikan ekstrak L.I.

Hasil yang diperoleh ini sejalan juga dengan penelitian yang dilakukan oleh (Runtuwene, et.,al 2017) yang menguji aktivitas antibakteri ekstrak bintang laut $L$. I yang diperoleh dari perairan pulau Siladen. Menurut penggolongan kekuatan daya antibakteri yang digolongkan menurut Davis and Stout (1971), yaitu: diameter zona bening $5 \mathrm{~mm}$ atau kurang dikategorikan lemah, zona bening $5-10 \mathrm{~mm}$ dikategorikan sedang, zona bening 10-20 mm dikategorikan kuat dan zona bening 10-20 $\mathrm{mm}$ atau lebih dikategorikan sangat kuat.

Penelitian ini juga menggunakan kontrol sebagai pembanding (kontrol negatif, kontrol positif). Kontrol positif yang digunakan dalam penelitian ini adalah antibiotik kloramfenikol, yang merupakan tolak ukur untuk menguji bioaktivitas antibakteri pada ekstrak kasar bintang laut. Kontrol negatif yang digunakan pada penelitian ini yaitu etanol. Kontrol negatif berfungsi untuk menguji ada tidaknya aktivitas antibakteri dari pelarut yang digunakan. Kontrol negatif menunjukkan tidak adanya zona hambat pada pengujian antibakteri terhadap bakteri Gram-negatif dan Grampositif.

Ekstrak bintang laut L. laevigata pada penelitian ini menunjukan adanya bioaktivitas yang berpotensi menghambat pertumbuhan bakteri E. coli. Pembuktian ini dapat menjadi suatu terobosan baru dalam penemuan obat antibakteri, karena sejauh ini pengendalian infeksi bakteri Gram-negatif seringkali menjadi kendala dalam bidang kedokteran, yang diakibatkan adanya karakteristik dari kelompok Gram negatif yang memiliki dinding peptidoglikan yang cukup padat dan kompak serta adanya efflux-pump mechanism yaitu suatu mekanisme untuk mengeluarkan senyawa-senyawa yang tidak dibutuhkan dalam proses biofarmasi seluler melalui sistem sekresi, sehinggga menghambat proses internalisasi senyawa untuk mempengaruhi mekanisme seluler dari bakteri (Posangi et. al., 2014; Bara et al., 2015).

\section{Kesimpulan}

a. Berdasarkan penelitian yang dilakukan bahwa bintang laut yang diambil dari perairan laut Tongkaiana Manado teridentifikasi jenisnya yaitu $L$. laevigata, $A$. typicus, $P$. nodosus. Berat dari ekstrak kasar L. laevigata $25.3 \mathrm{~g}$, A. typicus $14,9 \mathrm{~g}$, $P$. nodosus $32.3 \mathrm{~g}$,

b. Pada penelitian yang dilakukan ini ekstrak kasar dari bintang laut $L$. laevigata menunjukan daya hambat terhadap pertumbuhan bakteri E. coli. Sedangkan ekstrak kasar $A$. typicus dan $P$. nodosus tidak menunjukan aktivitas daya hambat terhadap ketiga bakteri uji ( $S$. agalactiae, $E$. colidan S. aureus.)

\section{Daftar Pustaka}

Achmad MJ, Isnansetyo A, Noer K, Ustadi, Kamiso.2014. Efek Imunostimulator Asam Lemak dari Bintang Laut (Acanthaster planci) terhadap Proliferasi Limfosit Secara In-Vitro. Squalen Bulletin of Marine \& Fisheries Postharvest \& Biotechnology, 9 (3), 2014, 107- 114.

Agustina, D.S. 2012. Aktivitas Antioksidan dan Komponen Bioaktif Bintang Laut Culcita sp.. [Skripsi]. Bogor agricultural university.

Bara, R., Kandou, A., Ola, G., Posangi, J. 2015. Analisis Senyawa Antibiotik dari 
Jamur Simbion Yang Terdapat dalam Ascidians Didemnum molle di Sekitar Perairan Bunaken Sulawesi Utara. Jurnal LPPM Bidang Sains dan Teknologi. 2:2835.

Davis, W.W., Stout, T.R. 1971. Disc Plate Method of microbiological assay. Journal of Microbiology. 22:659-665.

Juariah S. 2014. Aktivitas Senyawa Antibakteri Bintang Laut (Asterias forbesii) Terhadap Beberapa Jenis Bakteri Patogen. [Tesis]. Medan : Fakultas Matematika dan IImu Pengetahuan Alam, Universitas Sumatera Utara.

Lariman. 2011. Keanekaragaman Fylum Echinodermata di Pulau Beras Basah Kota Bontang Kalimantan Timur. Mulawarman Scientifie 10(2):207-218.

Hafiluddin. 2011. Ekstraksi dan identifikasi senyawa bioaktif lintah laut (Discodorissp.) sebagai antioksidan [Tesis]. Bogor : Sekolah Pascasarjana, Institut Pertanian Bogor.

Ivanchina NV, Kicha AA, Stonik VA. 2011. Steroid glycosides from marine organisms (Review).Steroids 76 : 425454.

Tarman K, Prestisia HN, Setyaningsih I, Meydia, Yogiara, Hwang JK. 2012. Kandungan Komponen Bioaktif dan Aktivitas Antimikrob Ekstrak Bintang Laut (Culcita schmideliana). JPHPI, Volume 15 Nomor 3.

Undap, N.I.J., Sumilat, D.A., Bara, R. 2017. Aktivitas Antibakteri Spons Agelas tubulata dan Phyllospongia sp. dari Perairan Pantai Malalayang Manado Terhadap Pertumbuhan Beberapa Strain Bakteri. Jurnal IImu dan Managemen Perairan. ISSN: 2337-5000. (Accepted). 5(1).

Madigan, M. T. Martinko. 2012. Brock Biology of Microorganisms. Edisi 13. San Francisco: Bejamin Cummings.

Mapila, D. A. 2012. Uji Aktivitas Antibakteri Ekstrak Etanol Daun Mayana (Coleus atropurpureus benth) Terhadap
Staphylococcus aureus, Escherichia coli dan Pseudomas aeruginosa Secara Invitro [skripsi]. Program Studi Farmasi FMIPA Universitas Sam Ratulangi, Manado.

Mojica, E., R. Layson, M. Rodil, C. Deocaris. 2003. Marine invertebrates as source of potential anti-tumor and antibacterial agents. 8th Southern Luzon Zonal R \& D Review, DLSU, 1: 1-11. 